\title{
Ficus platyphylla promotes fertility in female Rattus norvegicus Wistar strain: a preliminary study
}

Chinenye J Ugwah-Oguejiofor ${ }^{1 *}$, Shaibu O Bello ${ }^{1}$, Raymond U Okolo ${ }^{2}$, Emmanuel U Etuk ${ }^{3}$, Michael O Ugwah ${ }^{4}$ and Vincent U Igbokwe ${ }^{5}$

\begin{abstract}
Background: Ficus platyphylla Delile (family- Moracea) commonly called gutta percha tree is a deciduous plant found in savannah areas. It grows widely in the Northern part of Nigeria, up to $60 \mathrm{ft}$. high and is known as 'gamji' by the Hausas. The seeds, bark and leaves have been used traditionally in combination to promote fertility. Scientifically, the plant has been shown to have analgesic, anti-inflammatory and CNS effects. The present study was to validate the use of this plant to promote fertility in female Rattus norvegicus Wistar strain using various fertility parameters.
\end{abstract}

Methods: Female Rattus norvegicus Wistar strain weighing between 150-180 g were randomly selected and divided into two major groups. Each group was subdivided into 5 treatment groups of 100, 200, $400 \mathrm{mg} / \mathrm{kg}$ BW of aqueous extract of F. platyphylla and a control group of $5 \mathrm{ml} / \mathrm{kg}$ of distilled water. A positive control of clomiphene citrate was used. Treatment of the first group was discontinued after 15 days prior to mating (pre-mating treatment group), while the other was treated continuously till delivery (continuous treatment group). At the $10^{\text {th }}$ day, females were sacrificed and implantation sites were checked and embryos counted. Upon delivery, litter sizes were determined and the pups weighed and checked for deformities. Other reproductive indices were calculated. Data were analyzed by one-way analysis of variance and students T-test. Proportions were analysed by Chi square. Statistical evaluations were performed using STATS programs and Graphpad prism, and a difference was considered statistically significant at $\mathrm{P}<0.05$.

Results: There was a significant reduction in the percentage post implantation losses of both the pre-treatment and the continuous treatment groups when compared to their distil water controls. The litter size of the pretreatment group was similar to the distil water group while at $400 \mathrm{mg} / \mathrm{kg}$, the continuous treatment group showed an increase in the litter size similar to that of the clomiphene group. There were no observed external deformities in the pups.

Conclusions: Administration of aqueous extract of $F$. platyphylla promotes fertility by reducing post implantation loss and by increasing litter size in female Rattus norvegicus Wistar strain.

\section{Background}

Infertility in humans is defined by the failure to achieve pregnancy after 12 months or more of regular unprotected sexual intercourse [1]. It is a reproductive health problem which affects both men and women of reproductive age in all parts of the world [2,3]. In Nigeria,

\footnotetext{
* Correspondence: nenye789@yahoo.com

'Department of Pharmacology, Faculty of Pharmaceutical Sciences, Usmanu Danfodiyo University Sokoto, Nigeria

Full list of author information is available at the end of the article
}

estimates on the prevalence of infertility vary from region to region. In Africa, women bear the burden of infertility more than the men $[2,4,5]$. Various social implications associated with infertility abound which range from blame for reproductive failures to life threatening interventions [3]. Therefore, it is not unusual to find victims desperately searching for a solution to this malady.

Traditional medicine is of immense value in the health care systems of developing countries. The World Health

\section{Ciomed Central}


Organization (WHO) estimates that more than $80 \%$ of health care needs in these countries are met through traditional health care practices [6]. This may possibly be because its affordability and accessibility is more than that of the orthodox medicine $[7,8]$. A lot of herbs have been used traditionally to treat infertility for example, Lepidium meyenii (maca), Trifolium pretense (red clover), Dioscorea villosa (wild yam) etc. In the Northern part of Nigeria (Sokoto), F. platyphylla (gamji) has been used for this purpose.

F. platyphylla Del. Holl (Moraceae) which is commonly referred to as gutta percha tree, is a deciduous plant locally known as "gamji" in Hausa and widely distributed throughout the savannah region of West African coast.

Traditionally, F. platyphylla has been used to treat various fertility problems without scientific basis. Attempts have been made to study the plant but not in connection with its fertility promotion [9-11]. Previous studies on the stem bark of the plant revealed that it possesses antinociceptive, anti-inflammatory, and gastrointestinal activities $[9,10]$, it also has some CNS effects [11], in rodents.

In Sokoto, the decoction of the stem bark, leaves and seeds of this plant are used in combination and taken as tea to promote fertility. Currently, it is considered best practice in ethnopharmacology to evaluate ethnomedicines used; i.e in the form it is used in the traditional medical setting [12]. For this reason, this study was conducted on the extract of the leaves, plants and roots (combined) thus mimicking the way it is prepared for fertility purposes in the ethnomedicinal setting.

The present study was designed to examine the fertility promoting effect of aqueous extract of $F$. platyphylla in female Rattus norvegicus Wistar strain of reproductive age through several female reproductive indices and counting of the implanted embryos at various doses of the aqueous extract and comparing it with Clomiphene citrate.

Clomiphene citrate $(\mathrm{CC})$ is a nonsteroidal triphenylethylene derivative that exhibits both oestrogen agonist and antagonist properties [13]. It is a drug of choice for treatment of various forms of infertility and for ovulation induction [13].

\section{Methods \\ Animal}

Rattus norvegicus Wistar strain, of both sexes were obtained from Veterinary institute Vom, Jos in separate cages and kept in the animal house of the Department of Pharmacology Usmanu Danfodiyo University Sokoto.

The animals were kept in well constructed cages that allowed freedom of movement for two (2) weeks for acclimatization to the laboratory conditions before commencement of study. Water and standard rat chow were provided ad libitum throughout the period of the study.

180 Female rats weighing between 150-180 g were randomly selected and divided into two major groups. The first group was used to assess the effect of pretreatment of the animal with the extract, before mating (pre-mating group), while the second group was used to assess the effect on continuous treatment of the animals (continuous treatment group) [14]. The study was conducted in accordance with the Organization for Economic Development (OECD) guidelines on good laboratory practice [15].

\section{Preparation of the plant material}

The stem bark, leaves and seeds of F. platyphylla (Gamji) were obtained from the surroundings of Usmanu Danfodiyo University teaching hospital Sokoto on the $6^{\text {th }}$ of November 2008. They were identified at the Taxonomy unit of the Department of Botany, Usmanu Danfodiyo University Sokoto. Voucher specimen was deposited in the herbarium with voucher accession number 003.

They were washed with tap water, cut into pieces and air dried for about 10 days to constant weight. The dried material were pulverised mechanically using a grinding machine into a dry powder and weighed. The powder was subjected to soxhlet extraction using distilled water. The filtrates were evaporated in the oven at $50^{\circ} \mathrm{C}$. The extract was stored in a freezer from where it was used when required [16].

The clomiphene citrate used was branded Clomid ${ }^{\mathrm{R}}$ obtained from Sanofi-aventis, One Onslow Street, Guildford, Surrey GU1 4YS, UK.

\section{Treatment of animals for the experiment}

The female Rattus norvegicus Wistar strain in each of the two major groups were randomly selected and divided into 5 experimental groups $(n=20)$. The experimental groups consisted of two control groups and 3 treatment groups. The control groups received $5 \mathrm{ml} / \mathrm{kg}$ of the vehicle (distilled water) and clomiphene citrate while the treatment groups received $100 \mathrm{mg} / \mathrm{kg}, 200 \mathrm{mg} / \mathrm{kg}$ and $400 \mathrm{mg} / \mathrm{kg}$ body weights each of the extract respectively. The ciomiphene treated group served as control for both the pre-mating and the continuous treatment groups. All experimental groups were treated orally by gastric feeding every day for 15 days prior to mating except the clomiphene citrate group which was dosed for 5 days. On 16 th day, dosing was discontinued for the pre-mating treatment group while the continuous treatment group was treated continuously till delivery. 


\section{Mating procedure}

On the $16^{\text {th }}$ day, all the rats were housed two per male animal in a cage. Vaginal smears were examined every morning for detection of spermatozoa. The day on which spermatozoa was detected in vaginal smear was considered day 1 of pregnancy $[17,14]$.

\section{Evaluation of animals}

All the animals were inspected daily for signs of abortion, illness and prolong duration of pregnancy.

\section{Caesarean section for implantation sites}

On the 10th day of pregnancy corresponding to mid gestation period, half of the females in all the groups were sacrificed by cervical dislocation. The implantation sites were checked and the embryos counted and weighed.

\section{Reproductive indices}

All the remaining pregnant females were allowed to give birth to their offspring. From pregnancy day 19 the animals' cages were inspected for births. As soon as possible after birth the numbers of viable and death newborns were recorded, the pups were weighed and generally inspected for any deformity up to day 7 after birth.

The following reproductive indices were calculated [17]: Mating index defined as number of sperm positive females/number of mated females $\times 100$, Pregnancy index defined as number of pregnant females/number of sperm positive females $\times 100$, Delivery index defined as number of females delivering/number of pregnant females $\times 100$, Birth live index defined as number of live offspring/number of offspring delivered $\times 100$, Postimplantation loss index defined as number of implantation sites - number of live fetuses/number of implantation sites $\times 100$.

\section{Statistical analysis}

Data were tested for normal distribution and analyzed by one-way analysis of variance (ANOVA) and students T-test. Proportions were analysed by Chi square. Statistical evaluations were performed using STATS programs and Graphpad prism, and a difference was considered statistically significant at $\mathrm{P}<0.05$.

\section{Results}

\section{Outcome of fertility tests}

In the pre-mating treatment group, there was a significant difference in the percentage post implantation loss in all the treatment groups when compared to the distil water control group (Table 1). The $400 \mathrm{mg} / \mathrm{kg}$ showed the highest significant decrease in the percentage post implantation loss index than the control. The lower
Table 1 Outcome of fertility tests in the pre-mating treatment group

\begin{tabular}{lccccc}
\hline Outcome/Dose $(\mathbf{m g} / \mathbf{k g})$ & $\mathbf{1 0 0}$ & $\mathbf{2 0 0}$ & $\mathbf{4 0 0}$ & D. water & clomiphene \\
\hline Mated females & 20 & 20 & 20 & 20 & 20 \\
Sperm positive females & 20 & 20 & 20 & 20 & 20 \\
Preg. Females & 12 & 12 & 16 & 18 & 5 \\
Mating index(\%) & 100 & 100 & 100 & 100 & 100 \\
Preg. Index(\%) & 60 & 60 & 80 & 90 & 25 \\
Post implant. Loss index (\%) & $10^{\mathrm{a}}$ & $12^{\mathrm{a}}$ & $-1.30^{\mathrm{b}}$ & 32.77 & - \\
\hline
\end{tabular}

Preg.: Pregnancy, Implant.: Implantation. D. water = Distilled water. Data

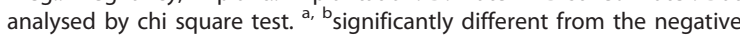
control at $\mathrm{P}<0.05$

doses $100 \mathrm{mg} / \mathrm{kg}$ and $200 \mathrm{mg} / \mathrm{kg}$ maintained the implantations more than the control (Table 1).

In the continuous treatment group, all the treatment groups showed significant decrease in the percentage post implantation loss index with the $400 \mathrm{mg} / \mathrm{kg}$ showing the highest reduction when compared to the distil water control group (Table 2).

The pregnancy index was lowest in the clomiphene treatment group (Tables 1 and 2). The clomiphene citrate group showed no implantation sites.

\section{Reproductive index}

The result of the reproductive index in the pre-mating treatment group showed no significant difference amongst the groups and when compared to the control. However, there was a significant increase in the number of the pups per litter of the rats by the clomiphene citrate group when compared to all the groups (Table 3).

In the continuous treatment group, the $400 \mathrm{mg} / \mathrm{kg}$ of the extract showed a significant increase in the number of pups per litter when compared to all the groups except the clomiphene treatment group. The number of pups' body weight of the same group was significantly more than that of the control groups (Table 4).

Table 2 Outcome of fertility tests in the continuous treatment group

\begin{tabular}{lccccc}
\hline $\begin{array}{l}\text { Outcome/Dose } \\
\text { (mg/kg) }\end{array}$ & $\mathbf{1 0 0}$ & $\mathbf{2 0 0}$ & $\mathbf{4 0 0}$ & D. water & clomiphene \\
\hline Mated females & 20 & 20 & 20 & 20 & 20 \\
$\begin{array}{l}\text { Sperm positive } \\
\text { females }\end{array}$ & 20 & 20 & 20 & 18 & 20 \\
Preg. Females & 16 & 18 & $20^{\mathrm{a}}$ & 14 & 5 \\
Mating index(\%) & 100 & 100 & 100 & 90 & 100 \\
Preg. Index(\%) & 80 & 90 & 100 & 70 & 20 \\
$\begin{array}{l}\text { Post implant. Loss } \\
\text { index (\%) }\end{array}$ & $-27.25^{\mathrm{b}}$ & $-31.05^{\mathrm{b}}$ & $-46.6^{*}$ & 29.45 & - \\
\hline
\end{tabular}

D. water = Distilled water. Data analysed by chi square test. ${ }^{*},{ }^{b}$ significantly different from the D. water group. ${ }^{\text {a }}$ significantly different from the clomiphene group. Values significant at $\mathrm{P}<0.05$. 
Table 3 Reproductive index in the pre-mating treatment group

\begin{tabular}{lccccc}
\hline $\begin{array}{l}\text { Reproductive index/ } \\
\text { Dose (mg/kg) }\end{array}$ & $\mathbf{1 0 0}$ & $\mathbf{2 0 0}$ & $\mathbf{4 0 0}$ & D. water & clomiphene \\
\hline No of (dams) pups & (5) 30 & $(5) 36$ & (6) 42 & $(6) 43$ & $(5) 45$ \\
No of pup per litter & $6.0 \pm 1.66$ & $7.33 \pm 4.10$ & $7.00 \pm 1.13$ & $7.17 \pm 2.12$ & $9.0 \pm 0.20^{*}$ \\
Pups body wt (g) & $5.17 \pm 1.38$ & $4.89 \pm 1.19$ & $4.82 \pm 0.16$ & $4.54 \pm 0.90$ & $4.59 \pm 0.15$ \\
Delivery index (\%) & 100 & 100 & 100 & 100 & 100 \\
Birth live index (\%) & 100 & 100 & 100 & 100 & 0 \\
No of pups with external malformations & 0 & 0 & 0 & 0 \\
\hline
\end{tabular}

D. water $=$ Distilled water. No of pups per litter are expressed as mean \pm S.D. Weights of pups are expressed as mean \pm S.E.M. ${ }^{*}$ Values are significant at $P<0.05$

\section{Gestation Length}

The gestation length was not significantly different from any of the groups and controls. For the 100, 200, 400, dist. water and Clomiphene citrate, the average gestation lengths were $21.22 \pm 0.28,22.08 \pm 0.08,22.3 \pm 0.02$, $21.82 \pm 0.33$, and $22.04 \pm 0.33$ respectively.

\section{Deformity}

On inspection of the pups at birth and daily up to the $7^{\text {th }}$ day of birth, there were no noticeable external deformities in all the treatment groups.

\section{Discussion}

The results of this study showed that the percentage implantation losses in the various doses of F. platyphylla in the pre-mating treatment group were less than the control, with the $400 \mathrm{mg} / \mathrm{kg}$ showing the least implantation loss index (Table 1). This suggests that the plant may contain constituents which may enhance or maintain pregnancy. Previous phytochemical studies on the plant, by Ugwah-Oguejiofor et al., 2011, showed that the plant contains steroids [18]. Various phytosteroids have been shown to promote fertility [14]. However the type of steroid present in F. platyphylla has not been evaluated.

The percentages of the F. platyphylla pre-mating treatment group that copulated (mating index) were similar in all the groups. The number of pregnant females was significantly more in the treatment groups than in the clomiphene citrate control group. The reason for this difference will need to be explored by further studies. One possible reason is that the plant may have a different mechanism of action although our data is insufficient to support this.

In the continuous treatment group, the fertility test was similar to that of the pre-mating treatment group, however the post implantation loss index was much less than that of the pre-mating group suggesting that during the continuous administration, the extract offered more protection to the embryos.

It has been shown that $F$. platyphylla causes a decrease in the total white blood cell count and lymphocytes which are functions of immune system [18]. It therefore implies that the possible mechanisms through which F. platyphylla may act include increased uterine receptivity and altered immune functions [19] even though more studies are needed to ascertain that. It is believed that functional lymphocytic progesterone binding sites are essential for the maintenance of normal pregnancy, and that progesterone-mediated immunosuppression is needed for the maintenance of normal gestation [20].

The pregnancy indices were similar in all groups except for clomiphene citrate group which was very low (Tables 1 and 2). This could be because even though clomiphene citrate (CC) is an ovulation inducer, its restoration of ovulation does not produce a much higher pregnancy rate. This inconsistency between ovulation and pregnancy rates (only 50\% of those who ovulate will conceive) may be partly explained by the peripheral anti-estrogenic effects of clomiphene citrate at the level of the endometrium and cervical mucus or by hyper

Table 4 Reproductive index in the continuous treatment group

\begin{tabular}{|c|c|c|c|c|c|}
\hline $\begin{array}{l}\text { Reproductive index/ } \\
\text { Dose }(\mathrm{mg} / \mathrm{kg})\end{array}$ & 100 & 200 & 400 & D. water & clomiphene \\
\hline No of (Dams) pups & (5) 26 & (5) 31 & (6) 50 & (5) 25 & (5) 45 \\
\hline No of pup per litter & $5.20 \pm 4.62$ & $6.2 \pm 3.06$ & $8.33 \pm 0.15^{*}$ & $5.00 \pm 2.06$ & $9.00 \pm 0.20$ \\
\hline Pups body weight(g) & $5.60 \pm 0.50$ & $5.92 \pm 0.08$ & $6.26 \pm 0.24^{*}$ & $4.83 \pm 0.61$ & $4.59 \pm 0.15$ \\
\hline Delivery index (\%) & 100 & 100 & 100 & 100 & 100 \\
\hline Birth live index (\%) & 100 & 100 & 100 & 100 & 100 \\
\hline No of pups with external malformations & 0 & 0 & 0 & 0 & 0 \\
\hline
\end{tabular}

D. water $=$ Distilled water. ${ }^{*}$ Values significant at $P<0.05$ 
secretion of luteinising hormone [21]. A poor prognosis for conception is indicated if the endometrial thickness on ultrasound scanning does not reach $8 \mathrm{~mm}$ at ovulation [21]. Experience has shown that the prevalence of endometrial suppression is one in every 6-7 patients [21].

Again, the litter size of animals treated with clomiphene citrate were higher than the distil water control (table 4) but similar to the $400 \mathrm{mg} / \mathrm{kg}$ treated group this could be because CC blocks the negative feedback mechanism which the rising estradiol levels would normally invoke to reduce discharge of Follicular Stimulating Hormone (FSH). The continued flow of FSH encourages multiple follicle development which is relatively common. The risk of multiple gestations is therefore increased and is estimated at $8-13 \%$ [22-24].

In the group treated continuously, it is interesting to note that the group dosed with $400 \mathrm{mg} / \mathrm{kg}$ body weight showed a significant increase in the litter size compared to the control and the other groups. This could mean that $F$. platyphylla may have a protective effect on the number of resorptions [20]. It is possible that the extract may help to prevent abortion. It may also increase the rate of multiple pregnancies.

In the reproductive index, both the pre-mating treatment group and the continuous treatment group showed no external malformations in their pups at all dose level until at day 7 . This again implies that the extract may not be teratogenic however; more studies are needed to conclude this and the mechanism through which this extract act is yet to be verified.

\section{Conclusions}

In conclusion, aqueous extract of the stem bark, leaves and seeds of $F$. platyphylla seems to promote fertility by maintaining uterine integrity and increasing the number of pups in female Rattus norvegicus Wistar strain without any noticeable teratogenic effect.

\section{List of Abbreviations}

CNS: Central Nervous System; CC: Clomiphene citrate; FSH: Follicle Stimulating Hormone.

\section{Acknowledgements}

The authors would wish to thank Mallam Muazu and Mr. Oga for their technical support. We thank also Mrs Cecilia Ugwah and Mr \& Mrs John Omezi for their financial assistance.

\section{Author details}

'Department of Pharmacology, Faculty of Pharmaceutical Sciences, Usmanu Danfodiyo University Sokoto, Nigeria. ${ }^{2}$ Department of Anatomy, College of health Sciences, Usmanu Danfodiyo University Sokoto, Nigeria. ${ }^{3}$ Department of Pharmacology, College of health Sciences, Usmanu Danfodiyo University Sokoto, Nigeria. ${ }^{4}$ Department of Pharmacy, Usmanu Danfodiyo University Teaching hospital, Sokoto, Nigeria. ${ }^{5}$ Department of Physiology, College of health Sciences, Usmanu Danfodiyo University Sokoto, Nigeria.

\section{Authors' contributions}

CJU conceive of the study, participated in its design, execution, analysis and interpretation of the data, and drafted the manuscript; OSB participated in the design, coordination, analysis and interpretation of the data, and assisted in proof reading the manuscript of the study; RUO assisted in execution of the experiment and revision of the manuscript; EUE participated in the development of the experiment and critically revised the manuscript; MOU assisted in execution of the experiment and revision of the manuscript; VUI participated in the development of the experiment and critically revised the manuscript.

All authors read and approved the final manuscript.

\section{Competing interests}

The authors declare that they have no competing interests.

Received: 9 September 2011 Accepted: 2 November 2011

Published: 2 November 2011

\section{References}

1. Larsen U: Research on infertility: which definition should we use? Fertil Steril 2005, 83(suppl 4):846-852.

2. Okonofua FE, Dianan H, Adetanwa O, Thomas K, Snow RC: The social meaning of infertility in Southwest Nigeria. Health Transit Rev 1997, 7:205-220.

3. Dintle KM: Denying and preserving self; Batswan women's experiences of infertility. Afr J Reprod health 2005, 9(suppl 2):26-37.

4. Inhorn MC: Interpreting Infertility: Medical anthropological perspectives. Soc Sci and Med 1994, 39(suppl 4):459-461.

5. Ademola A: Changes in the patterns of marriage and divorce in Yoruba town. Rural Afr J 1982, 14:16.

6. World Health Organization (WHO): WHO Traditional Medicine Strategy 20022005 World Health Organisation Geneva; 2002.

7. Sofowora A: Medicinal Plants and Traditional Medicine in Africa. 2 edition. Ibadan: Spectrum Books Ltd; 1993, 150.

8. Luoga EJ, Witkowski ETF, Balkwill K: Differential utilization and ethnobotany of trees in Kitulanghalo forest reserve and surrounding communal lands, eastern Tanzania. Econ Bot 2000, 54(suppl 3):328-343.

9. Amos S, Binda L, Chindo B, Akah P, Abdulrahman M, Danmallam HU, Wambebe C, Gamaniel K: Evaluation of methanolic extract of $F$. platyphylla on gastrointestinal activity. Indian J Exp Biol 2001, 39:63-67.

10. Amos S, Chindo B, Edmond I, Akah P, Wambebe C, Gamaniel K: Antinociceptive and anti-inflammatory properties of $F$. platyphylla stem bark. J Herbs Spices Med Plants 2002, 9:47-53.

11. Chindo BA, Amos S, Odutola AA, Vongtau HO, Abbah J, Wambebe C, Gamaniel KS: Central nervous system activity of the methanol extract of F. platyphylla stem bark. J Ethnopharmacol 2003, 85:131-137.

12. Reyes-García V: The relevance of traditional knowledge systems for ethnopharmacological research: theoretical and methodological contributions. J Ethnobiol Ethnomed 2010, 6:32.

13. Clark JH, Markaverich BM: The agonistic-antagonistic properties of clomiphene: a review. Pharmacol Ther 1982, 15:467-519.

14. Ruiz-Luna AC, Salazar S, Aspajo NJ, Rubio J, Gasco M, Gonzales GF: Lepidium meyenii (Maca) increases litter size in normal adult female mice. Reprod Biol Endocrinol 2005, 3:16.

15. Organization for Economic Development: Principles of Good Laboratory Practice. In hand Book of Good Laboratory Practice (GLP) TDR, PRD/GLP/01.2 2008.

16. Nwafor PA, Okwuasaba FK, Binda LG: Antidiarrhoel and antiulcerogenic effects of methanolic extract of Asparagus pubescens root in rats. $J$ Ethnopharmacol 2000, 72:421-427.

17. Mello FB, Jacobus D, Carvalho K, Mello JRB: Effects of Lantana camara (Verbenaceae) on general reproductive performance and teratology in rats. Toxicon 2005, 45:459-466.

18. Ugwah-Oguejiofor CJ, Bello SO, Etuk EU, Igbokwe VU, Ugwah OM Okolo RU: Preliminary toxicity and phytochemical studies of the aqueous extract of Ficus platyphylla in female albino rats. Afr J Pharm Pharmacol Res

19. Clark DA, Quarrington C, Banwatt D, Manuel J, Fupop G: Spontaneous abortion in immunodeficient SCID mice. Am J Reprod Immunol 1994 32:15-25. 
20. Szekeres-Bartho J, Chaouat G, Kinsky R: A Progesterone-induced blocking factor corrects high resorption rates in mice treated with antiprogesterone. Am J Obstet Gynecol 1990, 163:1320-1322.

21. Homburg R: Clomiphene citrate-end of an era? A mini-review. Hum Reprod 2005, 20(suppl 8):2043-2051

22. Eijkmans MJ, Habbema JD, Fauser BC: Characteristics of the best prognostic evidence: an example on prediction of outcome after clomiphene citrate induction of ovulation in normogonadotropic oligoamenorrheic infertility. Semin Reprod Med 2003, 21:39-47.

23. Scialli AR: The reproductive toxicity of ovulation induction. Fertil Steril 1986, 45:315-323.

24. Kousta E, White DM, Frank S: Modern use of clomiphene citrate in induction of ovulation. Hum Reprod Update 1997, 3:359-365.

doi:10.1186/1477-7827-9-145

Cite this article as: Ugwah-Oguejiofor et al:: Ficus platyphylla promotes fertility in female Rattus norvegicus Wistar strain: a preliminary study. Reproductive Biology and Endocrinology 2011 9:145.

\section{Submit your next manuscript to BioMed Central} and take full advantage of:

- Convenient online submission

- Thorough peer review

- No space constraints or color figure charges

- Immediate publication on acceptance

- Inclusion in PubMed, CAS, Scopus and Google Scholar

- Research which is freely available for redistribution

Submit your manuscript at www.biomedcentral.com/submit 